\title{
Are Grapevine Stomata Involved in the Elicitor-Induced Protection Against Downy Mildew?
}

\author{
Mathilde Allègre, Marie-Claire Héloir, Sophie Trouvelot, Xavier Daire, Alain Pugin, D. Wendehenne, and \\ Marielle Adrian \\ Unité Mixte de Recherche INRA 1088/CNRS 5184/ Université de Bourgogne Plante-Microbe-Environnement, 17 rue Sully, \\ BP 86510, 21065 Dijon cedex, France
}

Submitted 19 December 2008. Accepted 7 April 2009.

\begin{abstract}
Stomata, natural pores bordered by guard cells, regulate transpiration and gas exchanges between plant leaves and the atmosphere. These natural openings also constitute a way of penetration for microorganisms. In plants, the perception of potentially pathogenic microorganisms or elicitors of defense reactions induces a cascade of events, including $\mathrm{H}_{2} \mathrm{O}_{2}$ production, that allows the activation of defense genes, leading to defense reactions. Similar signaling events occur in guard cells in response to the perception of abscisic acid (ABA), leading to stomatal closure. Moreover, few elicitors were reported to induce stomatal closure in Arabidopsis and Vicia faba leaves. Because responses to ABA and elicitors share common signaling events, it led us to question whether stomatal movements and $\mathrm{H}_{2} \mathrm{O}_{2}$ production in guard cells could play a key role in elicitorinduced protection against pathogens that use stomata for infection. This study was performed using the grapevinePlasmopara viticola pathosystem. Using epidermal peels, we showed that, as for $A B A$, the elicitor-induced stomatal closure is mediated by reactive oxygen species (ROS) production in guard cells. In plants, we observed that the protection against downy mildew induced by some elicitors is probably not due only to effects on stomatal movements or to a guard-cell-specific activation of ROS production.
\end{abstract}

Stomata are structures regulating gas exchanges between the plant and the atmosphere (Assmann 1993; Zeiger 1983). They are formed by two guard cells that border a pore. In grapevine, they are mainly located in the lower epidermis of leaves. Stomatal opening and closure is under the control of external and internal stimuli such as light, $\mathrm{CO}_{2}$ concentration, atmospheric humidity, and phytohormones (Willmer and Fricker 1996). Among phytohormones, abscisic acid (ABA) plays an important role in the regulation of stomatal movements, promoting their closure or inhibiting their opening (McAinsh et al. 1990; Schroeder and Hagiwara 1990). ABA is involved in the plant response to water stress or drought. The ABAinduced stomatal closure involves a cascade of signaling events that has been partly decrypted (Desikan et al. 2004; Hetherington 2001). In particular, ABA perception by a receptor of the plasma membrane of guard cells (Shen et al. 2006)

Mathilde Allègre and Marie-Claire Héloir contributed equally to this article.

Corresponding author: M. Adrian; E-mail: marielle.adrian@u-bourgogne.fr; Fax: +33-3-80-69-32-26.

* The $\boldsymbol{e}$-Xtra logo stands for "electronic extra" and indicates that Figures $3,6,7$, and 8 appear in color online. induces protein kinase and phosphatase activities (Leung et al. 1997; Li and Assmann 1996; Mustilli et al. 2002), $\mathrm{H}_{2} \mathrm{O}_{2}$ (Wang and Song 2008), and nitric oxide (NO) (Neill et al. 2002) production. It also triggers increases in free cytosolic $\mathrm{Ca}^{2+}$ (Pei et al. 2000), contributing to the downregulation of plasma membrane inward-rectifying $\mathrm{K}^{+}$channels and activation of anion channels, leading to stomatal closure (Schroeder and Hagiwara 1989).

Stomata constitute natural openings that provide access to inner leaf tissues for many plant pathogens. Some pathogens force entry through closed stomata whereas others require opened stomata to successfully penetrate plants. In grapevine, Plasmopara viticola, the causal agent for downy mildew, uses stomata to penetrate into leaves and, next, to sporulate. Therefore, stomata are the first site of contact and molecular dialog between plants and such microorganisms. Some plants have evolved to close stomata in response to microbial perception (Melotto et al. 2008) but some microorganisms, such as the virulent strains of Pseudomonas syringae, are able to counteract this defensive strategy by inducing the reopening of stomata (Melotto et al. 2006). Other microorganisms are able to manipulate stomata, probably to facilitate sporulation, as described for Vitis vinifera cv. Marselan-Plasmopara viticola and Vicia faba-Sclerotinia sclerotiorum interaction (Allègre et al. 2007; Guimaraes and Stotz 2004).

In plants, the perception of potentially pathogenic microorganisms or elicitors of defense reactions, including pathogenor microbial-associated molecular patterns (PAMPs or MAMPs, respectively) (Jones and Dangl 2006), induces a cascade of signaling events, such as anion effluxes, $\mathrm{H}_{2} \mathrm{O}_{2}$ and $\mathrm{NO}$ production, protein kinase and phosphatase activation, and an increase in the concentration of cytosolic free calcium (Garcia-Brugger et al. 2006). The mobilization of these signaling events contributes to the transcriptional activation of defense genes encoding pathogenesis-related (PR) proteins and proteins involved in phytoalexin synthesis, cell-wall reinforcement, and hypersensitive reaction (HR) development. In grapevine, elicitors belonging to different chemical families were described for their ability to induce defense mechanisms or confer protection against pathogens. For example, we previously reported that endopolygalacturonase 1 from Botrytis cinerea (BcPG1) triggers ion fluxes, protein kinase activation, $\mathrm{H}_{2} \mathrm{O}_{2}$ and $\mathrm{NO}$ production, the accumulation of defense gene transcripts, and phytoalexin accumulation in Vitis vinifera cv. Gamay cell suspensions (Poinssot et al. 2003; Vandelle et al. 2006). The $\beta-1,3$ glucan laminarin induces similar events and confers protection against downy mildew and gray mold (Aziz et al. 2003). Chitosan also contributes to protect grapevine against B. cinerea (Ait Barka et al. 2004; Trotel-Aziz et al. 2006). Recently, Trouvelot 
and associates (2008) reported that the efficient protecting effects of the chemically sulfated laminarin PS3 against downy mildew is related to potentiated $\mathrm{H}_{2} \mathrm{O}_{2}$ production at the infection sites, upregulation of defense-related genes, callose and phenol depositions, and HR-like cell death. Similarly to $\beta$-aminobutyric acid (BABA), the mode of action of PS3 differs from elicitors because it confers protection to downy mildew through priming of defense reactions (Hamiduzzanam et al. 2005; Trouvelot et al. 2008). In some cases, grapevine defense reactions were reported to be associated with stomata. For example, Gindro and associates (2003) attributed the downy mildew tolerance of the hybrid Solaris to the filling of stomata and embedding of zoospores by callose secretions and deposits. A high accumulation of phenolic compounds in guard cells was also associated to the resistance of grapevine species to $P$. viticola (Dai et al. 1995).

Interestingly, the mechanisms underlying the effects of elicitor of defense responses and ABA-induced stomatal closure share common signaling events such as cytosolic free calcium accumulation, $\mathrm{H}_{2} \mathrm{O}_{2}$, NO production, and anion efflux. Few studies have investigated the effects of elicitors on guard cells. Lee and associates (1999) showed that oligogalacturonates inhibit light-induced stomatal opening and promote stomatal closure in tomato and Commelina communis epidermis. They also provided evidence that chitosan inhibits light-induced stomatal opening in tomato epidermis. In both cases, the effects of elicitors on stomata were mediated by $\mathrm{H}_{2} \mathrm{O}_{2}$ production and an increase in the concentration of free cytosolic calcium in guard cells. A reduction of the transpiration of pepper plants, suggesting a reduction of stomatal opening, was also observed following foliar treatment by chitosan (Bittelli et al. 2001). Klüsener and associates (2002) reported that fungal elicitors activate a stress signal transduction pathway in Arabidopsis guard cells, partly shared with ABA signaling pathway, especially an elevation in the concentration of free cytosolic calcium, leading to stomatal closure. These authors suggested a cross-talk mechanism between ABA and defense signaling in guard cells.

Taken together, these data led us to investigate whether grapevine stomata could be involved in elicitor-induced defense responses against $P$. viticola. The ability of various elicitors of defense responses to trigger stomatal movements and reactive

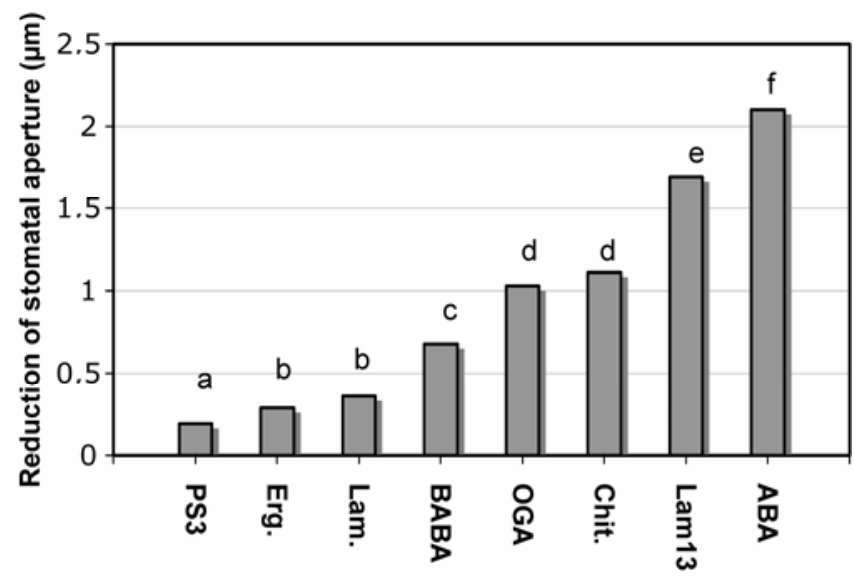

Fig. 1. Effect of elicitors $\beta$-aminobutyric acid (BABA), chitosan (Chit) $(500 \mu \mathrm{g} / \mathrm{ml})$, an oligogacturonide (OGA), laminarin (Lam), sulfated laminarin (PS3), and a laminarin of dp13 (Lam13) $(200 \mu \mathrm{g} / \mathrm{ml})$, ergosterol (Erg, $0.1 \mu \mathrm{M})$, and abscisic acid (ABA) $(50 \mu \mathrm{M})$ on the inhibition of stomatal opening in response to light stimulus, measured using epidermal peels. The data correspond to the mean difference of stomatal aperture between control and treated stomata. In our conditions, the mean pore diameter of control stomata was approximately $7.5 \mu \mathrm{m}$. Values with different letters $(\mathrm{a}, \mathrm{b}, \mathrm{c}, \mathrm{d}, \mathrm{e}$, and $\mathrm{f})$ are statistically different $(P<0.05)$. The value noted "a" is not significantly different from the control. oxygen species (ROS) production in guard cells was studied using epidermal peels. We have also analyzed whether elicitorinduced protection or natural resistance against $P$. viticola were partly mediated by ROS production in guard cells of grapevine plants grown in a greenhouse. Our results indicate that some elicitors of defense reactions trigger stomatal movements. Using epidermal peels, we showed that, as for ABA, their effect on the induction of stomatal closure is mediated by ROS production in guard cells. In grapevine plants, we observed that the protection against downy mildew induced by some elicitors is probably not due only to effects on stomatal movements or to a guard-cell specific activation of ROS production.

\section{RESULTS}

\section{Effects of elicitors on the inhibition of light-induced stomatal opening.}

The effects of elicitors belonging to different chemical families-ergosterol (lipid), laminarin and Lam13 ( $\beta-1,3$ glucans), PS3 (sulfated laminarin), OGA (oligogalacturonide), chitosan ( $\beta$-1,4 glucosamine), and BABA (synthetic amino-acid)—were assessed on stomatal movements using grapevine epidermal peels. For each compound, we had previously determined the concentration leading to a maximal and statistically significant reduction of stomatal aperture in response to light stimulus. This concentration was $500 \mu \mathrm{g} \mathrm{ml}^{-1}$ for BABA and chitosan; $200 \mu \mathrm{g} \mathrm{ml}^{-1}$ for laminarin, OGA, and Lam13; and $0.1 \mu \mathrm{M}$ for ergosterol (data not shown). Whatever the concentrations tested, PS3 did not induce any significant reduction of stomatal aperture (data not shown). However, for further studies, we decided to assess it at the same concentration as other oligosaccharides (i.e., $200 \mu \mathrm{g} \mathrm{ml}^{-1}$ ). Then, the effects on the inhibition of stomatal opening at light of all these elicitors, used at these optimal concentrations, were compared together and with ABA, using control conditions as reference (Fig. 1). As expected, ABA induced a strong and significant reduction of stomatal aperture (2.1 $\mu \mathrm{m}$ compared with the control). Ergosterol and laminarin induced a low but significant effect on stomatal aperture. The other elicitors triggered a greater reduction of stomatal opening at light, especially Lam13, that led to the highest reduction of the aperture, closed to ABA. As indicated above, PS3 had no significant effect.

The three oligosaccharidic elicitors PS3, OGA, and Lam13 were selected for further experiments on the basis of their effect on the inhibition of stomatal opening: no effect for PS3, moderate effect for OGA, and strong effect for Lam13.

\section{Effects of elicitors on the induction of stomatal closure at light.}

The mechanisms involved in stomatal opening differ from those involved in stomatal closure (Mishra et al. 2006); therefore, the three selected oligosaccharides were next assessed for their effect on the induction of stomatal closure at light (Fig. 2). Lam13 and ABA induced a similar and significant stomatal closure at light, with a reduction of 2.94 and $2.67 \mu \mathrm{m}$, respectively, compared with the control. OGA also induced a significant reduction of stomatal aperture, although weaker compared with Lam13 and ABA, whereas PS3 showed no significant effect. Then, we observed a similar efficiency for induction of stomatal closure and for the inhibition of stomatal opening.

\section{Effect of elicitors on the induction of grapevine protection against $P$. viticola.}

The three elicitors were compared for their ability to protect grapevine leaves against $P$. viticola (Fig. 3). Lam13 did not confer any protection against downy mildew. Hence, leaves showed severe symptoms and $P$. viticola sporulation was abundant. Both 
OGA and PS3 induced good levels of protection, especially PS3 (76\%). Indeed, sporulation was scarce on the surface of PS3treated leaves. These results are in agreement with those previously obtained by Trouvelot and associates (2008).

Therefore, these experiments enabled us to select elicitors having different effects on both stomatal movements and on the level of induced protection against $P$. viticola: Lam13 strongly inhibits stomatal opening and induces stomatal closure but does not confer protection against $P$. viticola, OGA impacts both stomata movements and protection against $P$. viticola, and PS3 has no effect on stomata but confers the highest level of protection against $P$. viticola.

\section{The ABA-induction of stomatal closure} reduces $P$. viticola infection of grapevine leaves.

We next determined whether the ABA induction of stomatal closure could limit or prevent leaf infection by $P$. viticola. Excised leaves were treated by petiolar absorption of ABA (50 and $100 \mu \mathrm{M}$ ) or water (as control). After $3 \mathrm{~h}$ of treatment, the transpiration of control leaves remained high $(937 \pm 292 \mu \mathrm{mol}$ $\mathrm{m}^{-2} \mathrm{~s}^{-1}$ ) whereas it was significantly reduced in ABA-treated leaves: $414 \pm 12$ and $279 \pm 20 \mu \mathrm{mol} \mathrm{m}^{-2} \mathrm{~s}^{-1}$ for 50 and $100 \mu \mathrm{M}$ ABA, respectively (Fig. 4A). These results indicate that ABA treatment has efficiently induced the closure of stomata. Leaf disks were next prepared from ABA-treated and control leaves and inoculated with $P$. viticola. At 24 h postinoculation (hpi), the number of sites of infection was determined by microscope observation. Means of 38,31, and 8 infected sites were observed for control disks and 50- and 100- $\mu \mathrm{M}$ ABA-treated disks, respectively (Fig. 4B). The values obtained for the control and $50 \mu \mathrm{M}$ ABA conditions are not statistically different but the treatment by $100 \mu \mathrm{M}$ ABA significantly reduced $P$. viticola infection. Similar results were obtained for the level of sporulation measured on control and ABA-treated disks (Fig. 4C). Despite the fact that both ABA concentrations similarly induced stomatal closure, only the $100 \mu \mathrm{M}$ concentration was efficient to limit infection and sporulation of the oomycete.

The excised leaves were also treated by petiolar absorption of Lam13, OGA, and PS3 to check their respective effect on transpiration. In contrast to what was observed on stomatal movements using epidermal peels, none of the elicitors induced a reduction of transpiration in leaves (Fig. 5A). In infrared thermography experiments, these elicitors had no significant effect compared with ABA (Fig. 5B).

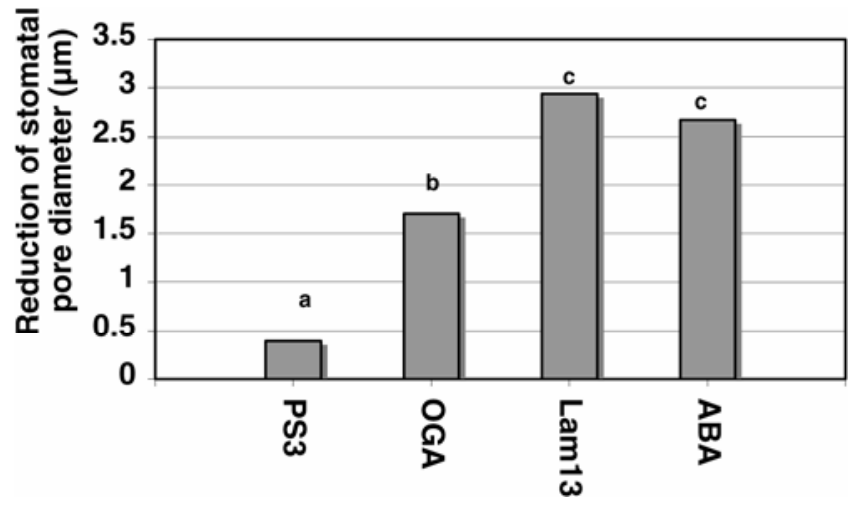

Fig. 2. Effect of sulfated laminarin (PS3), an oligogalacturonide (OGA) a laminarin of dp13 (Lam13) $(200 \mu \mathrm{g} / \mathrm{ml})$, and abscisic acid (ABA) $(50 \mu \mathrm{M})$ on the induction of stomatal closure at light, measured using epidermal peels. Values correspond to the mean reduction of the aperture in response to treatment, compared with the control. In our conditions, the mean pore diameter of control stomata was approximately $7.5 \mu \mathrm{m}$. Values with different letters $(\mathrm{a}, \mathrm{b}$, and $\mathrm{c})$ are statistically different $(P<0.05)$. The value noted "a" is not significantly different from the control.
Effects of ABA and elicitors on the production of ROS in guard cells using epidermal peels.

Epidermal peels were used to study the production of ROS in guard cells in response to PS3, OGA, and Lam13 in comparison with ABA treatment (Fig. 6). ABA induced a high production of ROS, as observed $60 \mathrm{~min}$ after the treatment. Lam13 also induced a high production of ROS, comparable with those obtained in response to ABA (approximately 70\% of the fluorescence detected in response to ABA) (Fig. 6A). Treatments by PS3 and OGA induced a ROS production that corresponds to approximately 31 and $45 \%$ of those induced by ABA, respectively (Fig. 6A).

\section{$\mathrm{H}_{2} \mathrm{O}_{2}$ production in leaves.}

$\mathrm{H}_{2} \mathrm{O}_{2}$ production was also studied in detached leaves of $\mathrm{cv}$. Marselan, a cultivar susceptible to downy mildew, $48 \mathrm{~h}$ after treatment by the three elicitors OGA, Lam13, and PS3 (Fig. 7) and 24 and 48 h following inoculation by $P$. viticola ( 72 and 96 $\mathrm{h}$, respectively, post treatment by the elicitor). For comparison, the production of $\mathrm{H}_{2} \mathrm{O}_{2}$ was studied in detached leaves from $V$. rupestris, a grapevine species tolerant to downy mildew. $\mathrm{H}_{2} \mathrm{O}_{2}$ was visualized by cytochemical analyses using diaminobenzidine (DAB) that precipitates in the presence of $\mathrm{H}_{2} \mathrm{O}_{2}$ to form an insoluble product visible as a brown $\mathrm{DAB}$ polymer at the sites of production.

PS3 did not induce the production of $\mathrm{H}_{2} \mathrm{O}_{2}$ in Marselan leaves. Indeed, as in the surfactant-treated leaves (Fig. 7A, control), no coloration could be detected in PS3-treated leaves before $P$. viticola inoculation, except in veins (Fig. 7D). The coloration observed in veins is due to the high peroxidase activity at this level and is generally used as a positive control for DAB staining (Thordal-Christensen et al. 1997). At $24 \mathrm{~h}$ following $P$. viticola inoculation, a high $\mathrm{H}_{2} \mathrm{O}_{2}$ production was detected in guard cells (Fig. 7E). At $48 \mathrm{hpi}, \mathrm{H}_{2} \mathrm{O}_{2}$ production was also observed in epidermal and parenchyma cells (Fig. 7F)

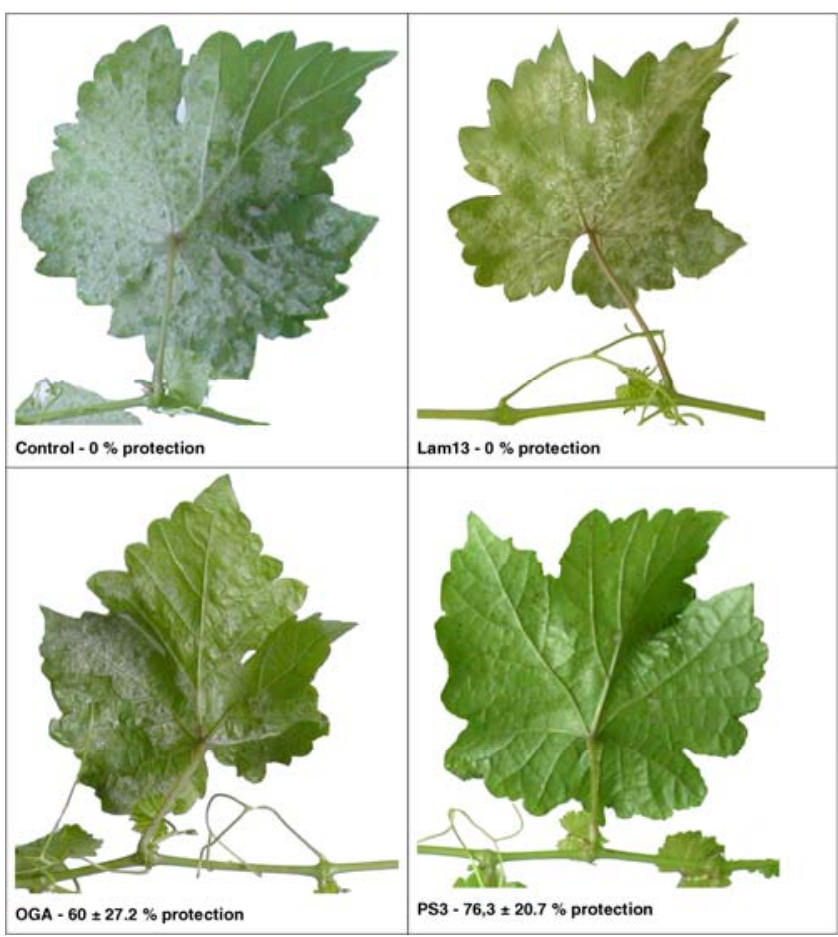

Fig. 3. Level of Plasmopara viticola infection of grapevine leaves 7 days postinoculation or 8 days post treatment by surfactant (control) or elicitors (laminarin of dp13 [Lam13], oligogalacturonide [OGA], and sulfated laminarin [PS3], $5 \mathrm{mg} / \mathrm{ml}$ added by surfactant). Photographs correspond to representative leaves observed for each indicated condition. 
whereas no coloration could be detected in control leaves (Fig. $7 \mathrm{~B}$ and C). As previously described (Trouvelot et al. 2008), $\mathrm{H}_{2} \mathrm{O}_{2}$ accumulation was associated with an alteration of $P$. viticola hyphae (collapsed hyphae) located in these areas (Fig. 8C
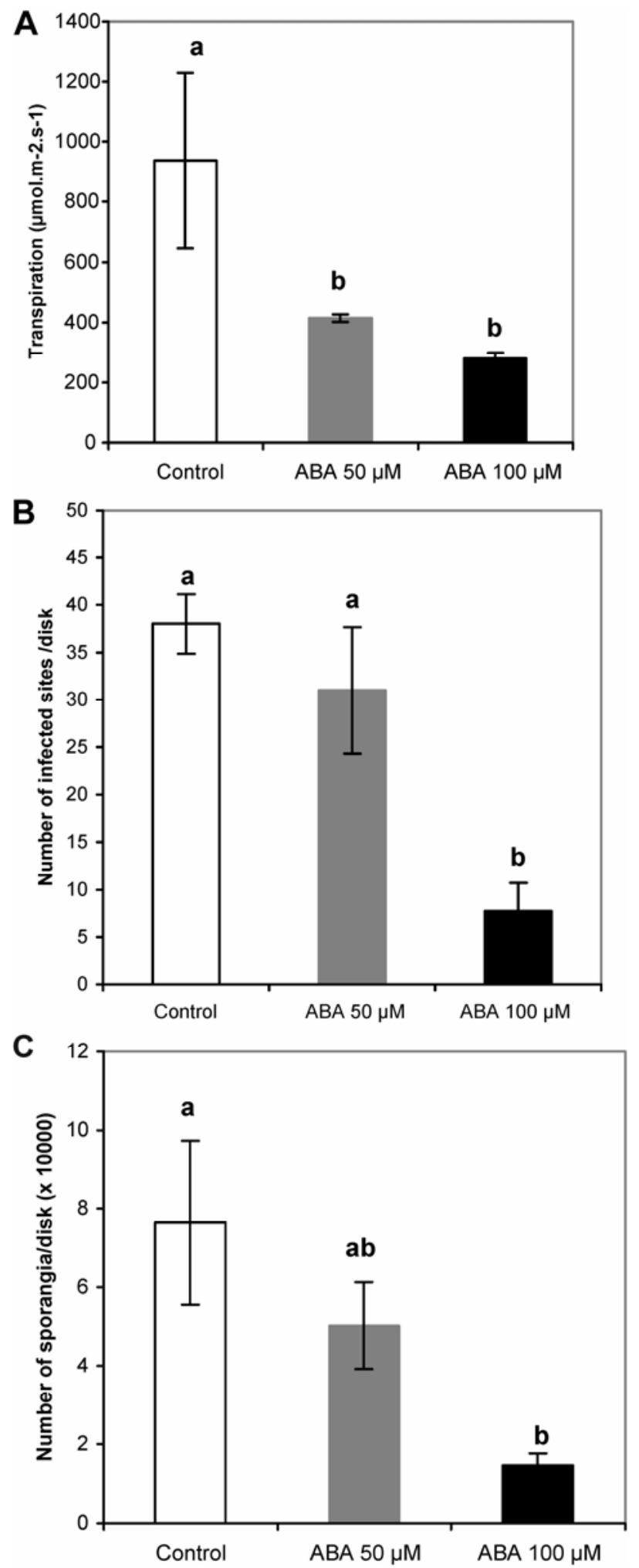

Fig. 4. Effect of abscisic acid (ABA) treatment (50 and $100 \mu \mathrm{M}$, petiolar absorption) on $\mathbf{A}$, leaf transpiration, $\mathbf{B}$, infection (zoospore penetration via stomata and formation of the first haustorium), and $\mathbf{C}$, sporulation of Plas mopara viticola. Data correspond to the mean \pm standard error calculated from values measured on leaves or disks; $a$ and $b$ indicate values significantly different $(P<0.05)$. and D). In contrast, in control leaves, where no $\mathrm{H}_{2} \mathrm{O}_{2}$ production was observed, hyphae developed normally (Fig. 8a and b).

A production of $\mathrm{H}_{2} \mathrm{O}_{2}$ was observed in leaves 2 days following treatment by OGA (Fig. 7G). This $\mathrm{H}_{2} \mathrm{O}_{2}$ production increased and extended in infected area following $P$. viticola inoculation. It was observed mainly in parenchyma cells and scarcely in guard cells (Fig. 7H and I) compared with what was observed in PS3-treated inoculated leaves. The high $\mathrm{H}_{2} \mathrm{O}_{2}$ accumulation sites corresponded to necrosis areas in which no hyphae could be distinguished (Fig. 8E and F). Next to these areas, where no DAB coloration occurred, $P$. viticola managed to develop (Fig. 8F). Lam13 also induced a production of $\mathrm{H}_{2} \mathrm{O}_{2}, 2$ days post treatment, located close to the main veins. This coloration was also observed in some stomata, epidermal, and parenchyma cells (Fig. 7J). However, it tended to decrease with time, even after $P$. viticola inoculation (Fig. 7K). DAB coloration was no longer detected 48 hpi (Fig. 7L). At this time, $P$. viticola development was similar to that observed in control leaves (Fig. 8G and $\mathrm{H}$ ).

In $V$. rupestris leaves, DAB-colored areas were observed in response to $P$. viticola (Fig. $7 \mathrm{M}$ through $\mathrm{O}$ ). $\mathrm{H}_{2} \mathrm{O}_{2}$ production was located in parenchyma and epidermal cells and, in some cases, in guard cells (Fig. 7O). P. viticola managed to develop in

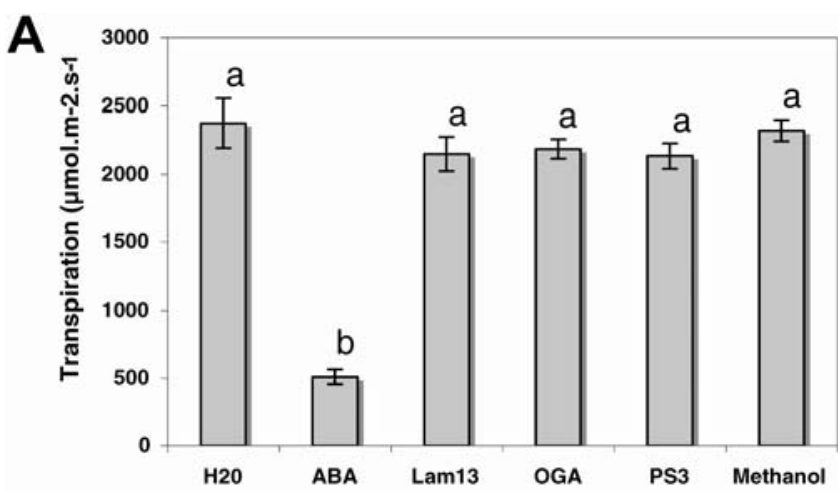

B
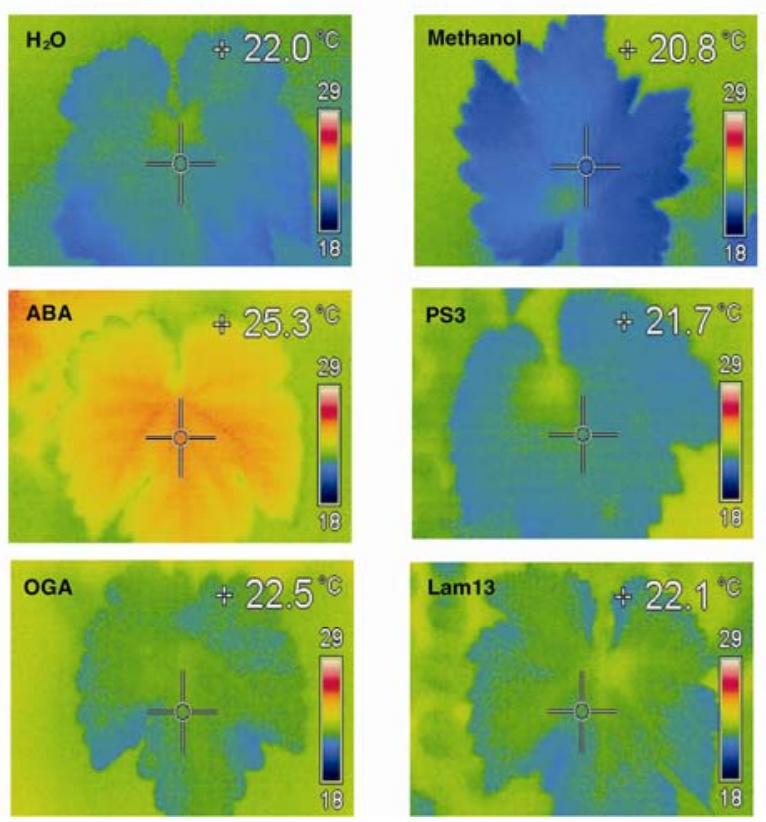

Fig. 5. Effect of the petiolar absorption of abscisic acid (ABA) $(50 \mu \mathrm{M})$, sulfated laminarin (PS3), an oligogalacturonide (OGA), and laminarin of dp13 (Lam13) $(100 \mu \mathrm{g} / \mathrm{ml})$ on leaf transpiration measured by A, gravimetry and $\mathbf{B}$, infra-red thermography. Data correspond to the mean \pm standard error calculated from values measured on $n$ leaves; $\mathrm{a}$ and $\mathrm{b}$ indicate values significantly different $(P<0.05)$. 
restricted areas. Hyphae presented a normal morphology in noncolored areas (Fig. 8J, arrow) whereas they looked altered in the area of $\mathrm{H}_{2} \mathrm{O}_{2}$ accumulation (Fig. 8J, arrowhead) as previously described for the tolerant hybrid Solaris (Trouvelot et al. 2008).

\section{DISCUSSION}

A temporal and partial induction of stomatal closure could be a strategy to protect grapevines against $P$. viticola. Some plants use it to avoid bacterial attacks or fungal penetration, such as soybean when it is infected by Phytophthora sojae. Recently, it was shown that a virulent strain of Pseudomonas syringae has evolved to reverse the induced stomatal closure in order to penetrate leaves (Melotto et al. 2006; Schulze-Lefert and Robatzek 2006). Few studies reported that elicitors of defense reactions are able to induce stomatal closure (Klüsener et al. 2002; Lee et al. 1999; Melotto et al. 2006). Thus, one objective of this study was to check whether elicitors able to induce the stomatal closure were efficient to confer protection against downy mildew.

Plasmopara viticola zoospores are actively attracted toward stomata, probably by chimiotactism (Kiefer et al. 2002;

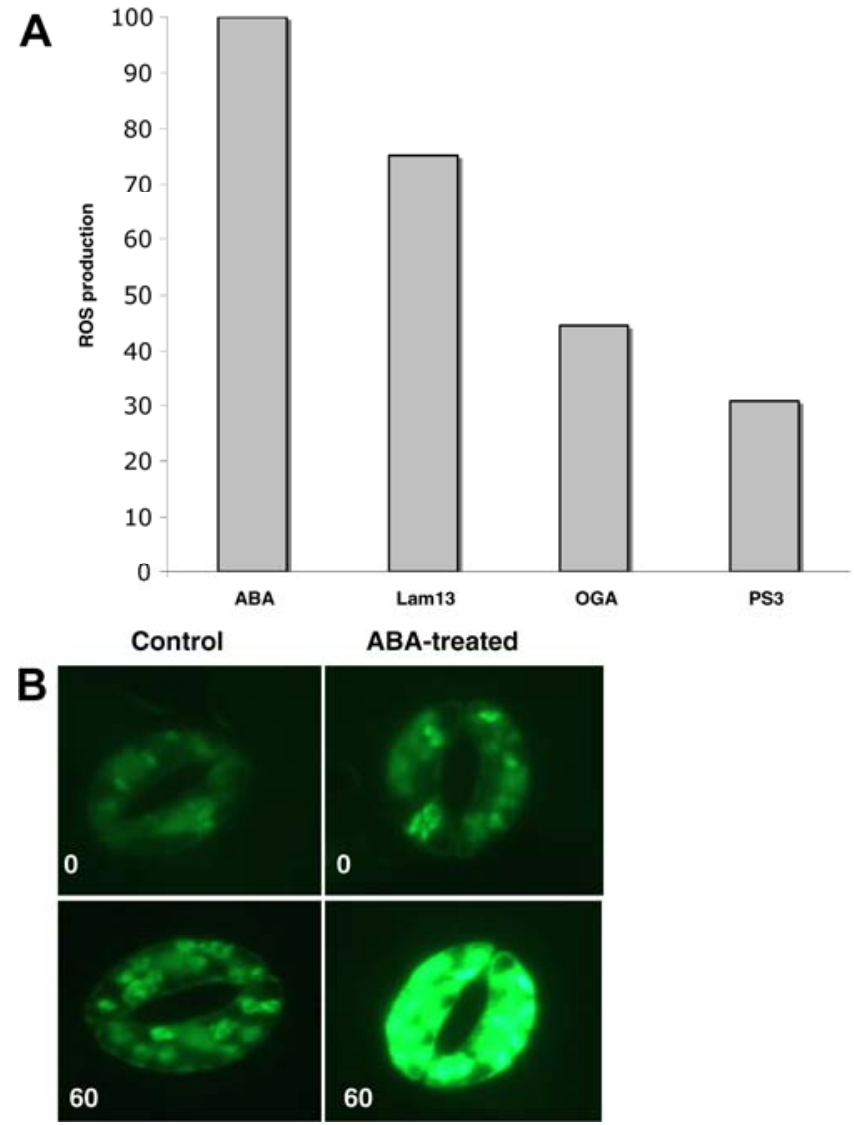

Fig. 6. Effect of laminarin of dp13 (Lam13), oligogacturonide (OGA), and sulfated laminarin (PS3) $(200 \mu \mathrm{g} / \mathrm{ml})$ on the induction of reactive oxygen species (ROS) production in guard cells compared with abscisic acid (ABA) $(50 \mu \mathrm{M}) \mathrm{A}$, ROS production in guard cells was detected from epidermal peels loaded with 2,7-DCFH-DA, 0 and $60 \mathrm{~min}$ following treatment. The mean intensity of the fluorescence was measured 10 min following $2,7-$ DCFH-DA loading in 16 guard cells per condition. Fluorescence was quantified as intensity of gray level of pixels measured in each guard cell minus the control value (time 0 ). The value 100 was attributed to the value measured for $\mathrm{ABA}$ and the values measured in response to elicitors were expressed as percentage of the ABA value. The graph corresponds to a significant experiment among three. B, Representative photographs of control and ABA-treated epidermal peels observed using a fluorescence microscope, 0 and 60 min following treatment.
Kortekamp 2003). Indeed, Kiefer and associates (2002) have shown that the ABA treatment (33 to $100 \mu \mathrm{M})$ of grapevine leaves reduces the stomatal attractivity for zoospores. Here, we showed that the ABA-induced stomatal closure significantly reduced $P$. viticola penetration in stomata and the subsequent level of infection. ABA, used at 50 to $100 \mu \mathrm{M}$, reduces the leaf transpiration in a similar manner. However, $50 \mu \mathrm{M}$ ABA did not limit $P$. viticola penetration whereas at $100 \mu \mathrm{M}$, the number of penetration sites was approximately 4.5-fold lower and the subsequent sporulation was reduced by approximately $80 \%$, as compared with nontreated leaves. Hamiduzzaman and associates (2005) also observed a small reduction of the number of $P$. viticola sporangia in grapevine leaf disks treated by $50 \mu \mathrm{M}$ ABA. However, they did not test higher concentrations. Our results suggest that $\mathrm{ABA}$ used at $100 \mu \mathrm{M}$ led to reduced infection. In addition to its effect on stomatal movements, ABA was reported to affect the plant resistance to pathogens (Audenaert et al. 2002; Flors et al. 2005; Mauch-Mani and Mauch 2005; Ton and Mauch-Mani 2004). It is generally reported that high levels of ABA tend to increase plant susceptibility to pathogens (Asselbergh et al. 2008; Bari and Jones 2009; Mauch-Mani and Mauch 2005). However, in a few cases, ABA was positively correlated to disease resistance. For example, ABA contributes to enhance the resistance of tobacco
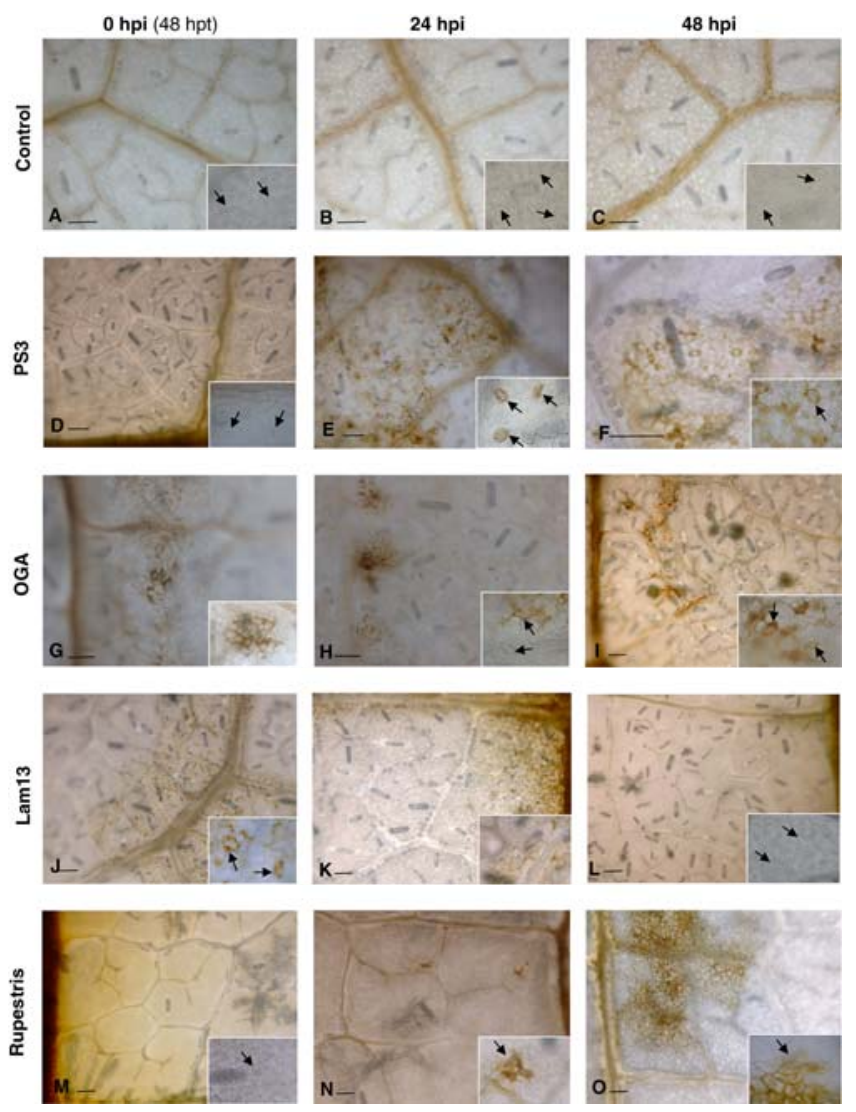

Fig. 7. $\mathrm{H}_{2} \mathrm{O}_{2}$ production in $\mathbf{A}$ through $\mathbf{L}$, Vitis vinifera cv. Marselan and $\mathbf{M}$ through $\mathbf{O}, V$. rupestris leaves. Marselan plants were previously sprayed with $\mathbf{A}$ through $\mathbf{C}$, surfactant $(0.05 \%)$ or $\mathbf{D}$ through $\mathbf{F}$, sulfated laminarin (PS3); $\mathbf{G}$ through $\mathbf{I}$, oligogacturonide (OGA); or $\mathbf{J}$ through $\mathbf{L}$, laminarin of dp13 (Lam13) $(5 \mathrm{mg} / \mathrm{ml}$ in $0.05 \%$ surfactant) and inoculated 2 days later by Plasmopara viticola. The $\mathrm{H}_{2} \mathrm{O}_{2}$ production was revealed $48 \mathrm{~h}$ post treatment (hpt), before $P$. viticola inoculation at $0 \mathrm{~h}$ postinoculation (hpi) (A, D, G, and J), 24 hpi (b, e, h, and k), and 48 hpi (C, F, I, and L). For V. rupestris, $\mathrm{H}_{2} \mathrm{O}_{2}$ production was detected before inoculation $(\mathrm{m}), 24 \mathrm{hpi}$ $(\mathrm{N})$, and 48 hpi $(\mathrm{O})$. Photographs are representative of the numerous observations performed. The experiment was repeated twice. Bars represent $100 \mu \mathrm{m}$. 
against the Tobacco mosaic virus by a downregulation of the $\beta$-1,3-glucanase responsible for callose degradation (Rezzonico et al. 1998). In addition, ABA may play a role in priming of callose production, as described for Arabidopsis-Alternaria brassicicola and Arabidopsis-Plectosphaerella cucumerina (Ton and Mauch-Mani 2004). Adie and associates (2007) have also reported that $\mathrm{ABA}$ is an essential signal leading to jasmonic acid biosynthesis and enhanced resistance of Arabidopsis to the oomycete Pythium irregularie. Therefore, in addition to effects on stomatal movements, high ABA concentrations may contribute to the activation of defense reactions in the grapevine-Plasmopara viticola interaction. This point would merit further investigation.

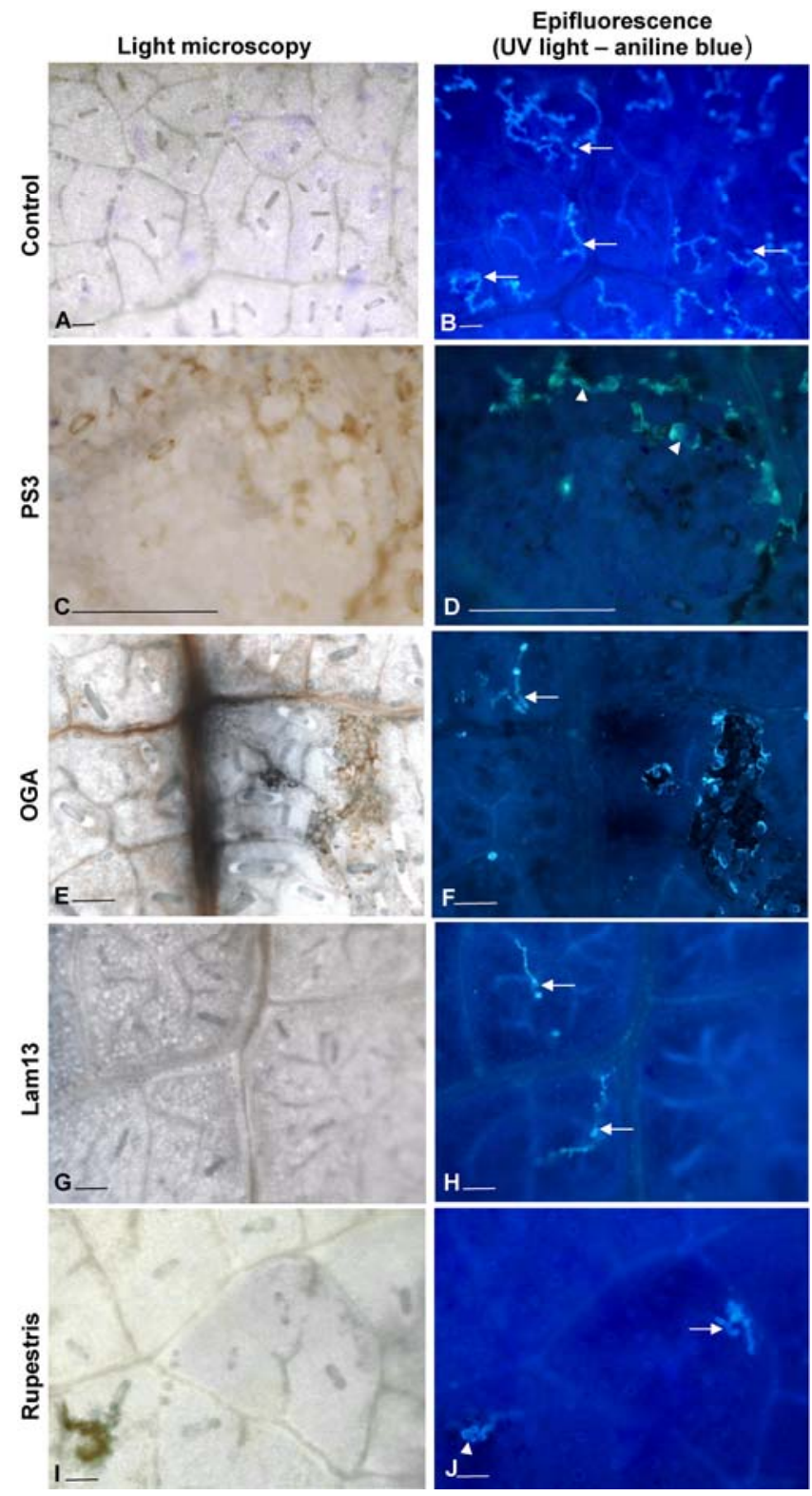

Fig. 8. $\mathrm{H}_{2} \mathrm{O}_{2}$ production and Plasmopara viticola development in A through $\mathbf{H}$, Vitis vinifera $\mathrm{cv}$. Marselan and $\mathbf{I}$ and $\mathbf{J}, V$. rupestris leaves. At $48 \mathrm{~h}$ following inoculation by $P$. viticola, $\mathrm{H}_{2} \mathrm{O}_{2}$ production was revealed using diaminobenzidine (A, C, E, G, and I). The development of the oomycete in the inner tissue was revealed using aniline blue staining $(\mathrm{B}, \mathrm{D}$, $\mathrm{F}, \mathrm{H}$, and $\mathrm{J}$ ). Arrows show altered hyphae of $P$. viticola and arrowheads indicate altered hyphae. Photographs are representative of the numerous observations performed. PS3 = sulfated laminarin, OGA = oligogacturonide, and Lam13 = laminarin of dp13. The experiment was repeated twice. Bars represent $100 \mu \mathrm{m}$.
Elicitors of different chemical nature did not present the same efficiency to inhibit stomatal opening in response to light stimulus. Moreover, as previously described regarding to the activation of defense reactions (Ménard et al. 2004), the degree of polymerization of oligosaccharides might also be a determinant for their efficiency on stomatal movements. Indeed, Lam13, a $\beta$-glucan of degree of polymerization (dp) approximately 13 glucose units, induced a higher inhibition of stomatal opening than laminarin, the same $\beta$-glucan with a dp of 25. Three oligosaccharides, PS3, OGA, and Lam13, which triggered no, moderate, and high inhibition of stomatal opening, respectively, were selected. Because the signaling and mechanisms involved in stomatal opening differ from those involved in stomatal closure, these compounds were compared for their ability to induce stomatal closure in light conditions. Similar results were obtained, with Lam13 being the most efficient and PS3 showing no significant effect. These results indicate that, in our conditions, each elicitor tested presents its own level of efficiency regarding stomatal movements and is similar for both inhibition of stomatal opening and induction of stomatal closure. It is the first time, to our knowledge, that the effects of different elicitors on grapevine stomatal movements have been reported.

The three elicitors were next compared for their ability to protect the susceptible grapevine Marselan grown in a greenhouse against $P$. viticola. PS3 induced the highest level of protection (approximately 76\%), followed by OGA (approximately 60\%), whereas Lam13 did not confer any protection and leaves presented severe disease symptoms. Consequently, OGA induced stomatal closure in epidermal peels and also protected grapevine plants against downy mildew whereas Lam13 induced stomatal closure but did not protect grapevine. The induction of stomatal closure by Lam13 may be necessary but not sufficient to confer protection against downy mildew. Conversely, PS3 had no effect on stomata but offered the highest level of protection against downy mildew. PS3 is known to act by priming defense reactions (Trouvelot et al. 2008). Thus, using epidermal peels, effects on stomatal movements may have been impossible to detect in the absence of $P$. viticola infection. However, we showed that BABA, which also acts by priming (Hamiduzzaman et al. 2005), induced stomatal movements in epidermal peels. These results suggest that PS3 and BABA might act differently on guard cells, for which it was difficult to correlate the effects of an elicitor on stomatal movements (measured using epidermal peels) and its efficiency to confer protection of grapevine plants against downy mildew. Elicitor treatment of leaves by petiolar absorption did not induce a reduction of transpiration. Petiolar absorption may not allow elicitors to reach guard cells. We also attempted to measure the stomatal conductance of leaves sprayed by elicitors (in the same conditions as for protection tests). However, the results (not presented) were highly variable and difficult to analyze. Hence, depending on the experiments, the elicitors showed either no effect or a reduction of stomatal conductance, suggesting a stomatal closure. These results suggest that the perception by guard cells of intact leaves is also highly variable. It may also be due to the number of stomata actually affected by the spray. In our experiments, some elicitors (Lam 13 and OGA) were able to induce reproducible stomatal movements in epidermal peels but were not systematically able to reduce transpiration when sprayed on leaves. We cannot exclude the possibility that they induce a stomatal closure in leaves. Moreover, OGA induces a reproducible level of protection against downy mildew whereas Lam13 does not protect against it. These data suggest that stomatal closure may contribute to induce protection against $P$. viticola but remains insufficient to limit infection. In contrast, PS3 does not induce stomatal movements in epidermal peels but confers a high and regular 
level of protection against $P$. viticola. It appears that, for this compound, effects on stomatal movements may not be required for protection.

Some events involved in the ABA- and elicitor-induced stomatal closure are similar to those involved in the elicitorinduced defense reactions. Lee and associates (1999) showed that the induction of stomatal closure by chitosan and an oligogalacturonide requires the production of $\mathrm{H}_{2} \mathrm{O}_{2}$, as in response to ABA. Chitosan and yeast extracts induce an increase of cytosolic-free calcium in guard cells prior to stomatal closure (Klüsener et al. 2002). In Arabidopsis epidermal peels, the induction of stomatal closure by flg 22 and lipopolysaccharide from bacteria shares the ABA signaling pathway and involves, in particular, the protein kinase OST1 and NO (Melotto et al. 2006). We decided to follow one of these signaling events, the production of ROS, in guard cells in response to ABA or the oligosaccharidic elicitors. Hence, ROS production is an important signaling event in the activation of defense reactions by elicitors and pathogens (Davies et al. 2006; Lamb and Dixon 1997; Levine et al. 1994). ROS have different roles regarding plant defense reactions: i) they constitute signaling events responsible for mitogen-activated protein kinase activation, increase of cytosolic $\mathrm{Ca}^{2+}$ concentration (Lecourieux et al. 2002), and activation of defense genes (Jabs et al. 1997); ii) they contribute to cell-wall strengthening by increasing lignification (Bruce and West 1989) and cross linking of proteins and phenolic compounds (Bradley et al. 1992; Brisson et al. 1994); and iii) their production at the infection site precedes the HR (Heath 1980). In epidermal peels, ABA induced a high production of $\mathrm{H}_{2} \mathrm{O}_{2}$ as described for Arabidopsis thaliana (Suhita et al. 2003). Lam13, which induced a high stomatal closure, also induced a high production of $\mathrm{H}_{2} \mathrm{O}_{2}$, similar to those obtained in response to ABA. OGA, and especially PS3, induced a lower production of $\mathrm{H}_{2} \mathrm{O}_{2}$. As previously discussed, the fact that PS3 acts by priming may explain this result. The elicitors efficient to induce the stomatal closure also induce the production of $\mathrm{H}_{2} \mathrm{O}_{2}$. These results suggest that, in grapevine, as in Arabidopsis, Vicia faba, and tomato (Lee et al. 1999; Suhita et al. 2003), the elicitor-induced stomatal closure is probably mediated by $\mathrm{H}_{2} \mathrm{O}_{2}$ production in guard cells.

As discussed above, ROS are also involved in defense reactions. Lam13 induces a high production of $\mathrm{H}_{2} \mathrm{O}_{2}$ in guard cells but does not protect grapevines against downy mildew. Conversely, OGA and PS3, efficient to confer protection, induce a lower production of $\mathrm{H}_{2} \mathrm{O}_{2}$. An elicitor-induced production of $\mathrm{H}_{2} \mathrm{O}_{2}$ in guard cells cannot be correlated to the elicitor-induced protection against downy mildew.

We also investigated the production of $\mathrm{H}_{2} \mathrm{O}_{2}$ in leaves from plants sprayed with elicitors and next inoculated by $P$. viticola, using DAB. In Vitis rupestris, a species tolerant to downy mildew, $\mathrm{H}_{2} \mathrm{O}_{2}$ was detected in some stomata and, more frequently, in epidermal and parenchyma cells. It was frequently associated with the presence of abnormal $P$. viticola hyphae. In some cases, $P$. viticola managed to develop but the infected areas were never associated with $\mathrm{H}_{2} \mathrm{O}_{2}$ accumulation. All these results confirm that $\mathrm{H}_{2} \mathrm{O}_{2}$ production is a component of grapevine defense reactions against $P$. viticola and contributes to limit its development. In the downy-mildew-susceptible grapevine $\mathrm{cv}$. Marselan, no $\mathrm{H}_{2} \mathrm{O}_{2}$ production could be detected following $P$. viticola inoculation, and hyphae developed normally. However, the production of $\mathrm{H}_{2} \mathrm{O}_{2}$ was detected in response to the treatment by the elicitors OGA and Lam13, before inoculation. $\mathrm{H}_{2} \mathrm{O}_{2}$ accumulation was observed in guard cells and occurred in epidermal and parenchyma cells, too. These data were in accordance with those obtained using epidermal peels, suggesting that this model was suitable for studying $\mathrm{H}_{2} \mathrm{O}_{2}$ production in guard cells.
Following $P$. viticola inoculation, $\mathrm{H}_{2} \mathrm{O}_{2}$ production increased in leaves treated by OGA whereas it decreased in leaves treated with Lam13, which may partly explain the different level of protection observed in response to both compounds. PS3 treatment of leaves did not induce detectable $\mathrm{H}_{2} \mathrm{O}_{2}$ production. However, after inoculation, a high $\mathrm{H}_{2} \mathrm{O}_{2}$ production was observed in infected sites, first in guard cells and then in epidermal and parenchyma cells. This particular response confirms that PS3 acts by priming defense reactions (Trouvelot et al. 2008). In the area of $\mathrm{H}_{2} \mathrm{O}_{2}$ production, the $P$. viticola hyphae also looked altered, confirming that $\mathrm{H}_{2} \mathrm{O}_{2}$ production contributes to limit its development. $\mathrm{H}_{2} \mathrm{O}_{2}$ production was detected in some guard cells but not specifically because it was generally observed in epidermal and parenchyma cells, two sites of haustoria development.

Some of the elicitors tested in this work are able to induce the closure of grapevine stomata, suggesting that this mechanism may contribute to limit $P$. viticola infection. However, it does not seem to be systematically required or sufficient to explain the level of protection conferred, confirming that the induced defense compounds, including $\mathrm{H}_{2} \mathrm{O}_{2}$, remain essential to limit leaf infection by downy mildew.

\section{MATERIALS AND METHODS}

\section{Plant material.}

Grapevine (V. vinifera L. cv. Marselan and V. rupestris, susceptible and tolerant, respectively, to downy mildew), herbaceous cuttings were grown in individual pots $(10$ by 7 by 7 $\mathrm{cm})$ containing a mixture of peat/sand/perlite $(5: 1: 1, \mathrm{vol} / \mathrm{vol} /$ $\mathrm{vol}$ ) in a greenhouse at temperatures of 24 and $18^{\circ} \mathrm{C}$ (day and night, respectively) and a relative humidity ( $\mathrm{RH})$ of $70 \%$ until they had developed six leaves. Plants were watered daily and fertilized weekly (PlantProd, Puteaux SA, France).

\section{Chemical compounds.}

Oligosaccharides: laminarin (a $\beta$-glucan with a dp of 25), Lam13 (the same $\beta$-glucan as laminarin but with a dp of 13), PS3 (sulfated laminarin), and an OGA (structure kept confidential) were provided by Goëmar SA (St. Malo, France). Chitosan was supplied by G. Roblin (University of Poitiers, France). All other chemical compounds were purchased from Sigma-Aldrich (St. Louis).

\section{Elicitor treatment of plants.}

Experiments were performed on grapevine plants grown in a greenhouse in the conditions described above. They were sprayed by elicitor solution (Lam13, OGA, and PS3 at $5 \mathrm{mg}$ $\mathrm{ml}^{-1}$ ) combined with surfactant (kept confidential; $0.05 \%$ in water as control) or surfactant alone on both the upper and lower leaf surfaces until the point of run-off.

\section{P. viticola inoculation.}

$P$. viticola isolated in a Burgundy vineyard was maintained on cv. Marselan susceptible plants. Sporangia were collected from sporulating leaves using a brush and suspended in distilled water. The concentration was adjusted to $10^{4}$ sporangia per milliliter using a Malassez hemacytometer. For inoculation, the abaxial side of leaves was sprayed by the sporangia suspension and placed overnight at a RH of $100 \%$. Plants were then placed in the greenhouse in the conditions described above.

\section{Visualization of $P$. viticola in leaf tissues.}

Leaf disks ( $7 \mathrm{~mm}$ in diameter) were clarified for $45 \mathrm{~min}$ in $10 \% \mathrm{KOH}(\mathrm{wt} / \mathrm{vol})$ at $90^{\circ} \mathrm{C}$ and rinsed twice in distilled water. They were stained in aniline blue $(0.05 \%, \mathrm{wt} / \mathrm{vol})$ in phosphate 
buffer (0.1 M, pH 8) overnight, mounted in the aniline blue solution, and examined by epifluorescence microscopy with a Leica DMLB microscope (Leica Microsystems, Heerbrugg, Switzerland) equipped with filter A ( $\lambda$ exc 340 to $380 \mathrm{~nm}, \lambda$ em $425 \mathrm{~nm}$ ) and a digital camera.

\section{Determination of the level of infection.}

On leaf disks. Ten leaf disks (10 $\mathrm{mm}$ in diameter) were deposited on moist filter paper and inoculated by a sporangia suspension $\left(2 \times 10^{4}\right.$ sporangia per milliliter $)$. At $24 \mathrm{~h}$ following inoculation, five disks were fixed overnight in $100 \%$ methanol, clarified in chloral hydrate solution $\left(2.5 \mathrm{~g} \mathrm{ml}^{-1}\right)$ overnight, and stained in aniline blue $(0.05 \%$, wt/vol $)$ as described before. Each disk was observed using an epifluorescence microscope to determine the number of infected sites (occurrence of small hyphae). The other five disks remained on moist filter paper until sporulation. Then, they were collected in $5 \mathrm{ml}$ of $50 \%$ ethanol (vol/vol) and sporangia were counted using a hemacytometer cell.

On plants. Six elicitor-sprayed plants (7 days postinoculation) were placed in high humidity condition (100\% RH) overnight to provoke $P$. viticola sporulation. Disease intensity was assessed by measuring the leaf area covered by sporulation.

\section{Epidermal peels.}

Leaves from grapevine plants were harvested at the end of the dark period and epidermal peels were prepared as previously described (Allègre et al. 2007). Briefly, the abaxial side of a leaf area was fixed with silicon adhesive (Telesis, Premiere Products, Pacoima, CA, U.S.A.) on a glass slide and the mesophyll was removed using forceps. The epidermal peels so obtained were washed in water and placed in petri dishes containing an equilibration buffer (10 mM Mes- $\mathrm{KOH}, \mathrm{pH}$ 6.5) (A. Vavasseur, personal communication) for $30 \mathrm{~min}$ at $24^{\circ} \mathrm{C}$ in darkness.

\section{Inhibition of stomatal opening at light.}

After the equilibration step, epidermal peels were transferred to individual petri dishes $(3 \mathrm{~cm}$ in diameter) containing $5 \mathrm{ml}$ of opening medium $(50 \mathrm{mM} \mathrm{KCl}, 10 \mathrm{mM}$ Mes$\mathrm{KOH}, \mathrm{pH} 6.5)$ added to the compounds to be assessed: ABA $(50 \mu \mathrm{M})$, methanol $(0.25 \%$ [vol/vol] as control $)$, and elicitors chitosan $(10$ to $500 \mu \mathrm{M})$, ergosterol $(0.01$ to $5 \mu \mathrm{M})$, BABA (50 to $500 \mu \mathrm{M}$ ), laminarin, Lam13, PS3, and OGA (50 to 200 $\mathrm{mg} \mathrm{ml}^{-1}$ ). The petri dishes were placed in the light (photosynthetic photon fluent rate [PPFR]: $350 \mu \mathrm{mol} \mathrm{m} \mathrm{m}^{-2} \mathrm{~s}^{-1}$ ) at $24^{\circ} \mathrm{C}$ for $3 \mathrm{~h}$ to promote stomatal opening. Before making observations, fluorescein diacetate $\left(20 \mu \mathrm{g} \mathrm{ml}^{-1}\right)$ was added to the preparation in order to visualize stomata presenting two living guard cells. Pictures of 24 stomata per epidermal peel were recorded using a Leica DMLB fluorescence microscope equipped with a digital camera and the stomatal apertures were measured using the FW4000i software. The results presented correspond to the mean of the values of three different experiences.

\section{Induction of stomatal closure at light.}

Epidermal peels were transferred to individual petri dishes ( $3 \mathrm{~cm}$ in diameter) containing $5 \mathrm{ml}$ of the opening medium (30 $\mathrm{mM} \mathrm{KCl}, 10 \mathrm{mM}$ Mes- $\mathrm{KOH}, \mathrm{pH} 6.5)$ and placed in the light (PPFR: $350 \mu \mathrm{mol} \mathrm{m} \mathrm{m}^{-2}$ ) at $24^{\circ} \mathrm{C}$ for $3 \mathrm{~h}$ to promote stomatal opening. Then, the compounds to be assessed for the induction of stomatal closure were added directly to petri dishes: ABA $(50 \mu \mathrm{M})$, methanol $(0.25 \%$ [ $\mathrm{vol} / \mathrm{vol}]$ as control $)$, and elicitors (Lam13, PS3, and OGA at $200 \mu \mathrm{g} \mathrm{ml}^{-1}$ ). Observations were made $2 \mathrm{~h}$ later, as described above for the inhibition of stomatal opening.
ROS detection in guard cells treated by elicitors.

$\mathrm{H}_{2} \mathrm{O}_{2}$ production in guard cells was monitored using $\mathrm{H}_{2}$ DCFH-DA, as previously described (Murata et al. 2001). Epidermal peels were placed in conditions to promote stomatal opening. Then, ABA $(50 \mu \mathrm{M})$ or elicitors (Lam13, PS3, or OGA at $200 \mu \mathrm{g} \mathrm{ml}^{-1}$ ) were added for 0 and $60 \mathrm{~min}$. At $10 \mathrm{~min}$ prior to the end of incubation time and observation, $\mathrm{H}_{2} \mathrm{DCFH}-$ DA (50 $\mu \mathrm{M}, 0.1 \%$ dimethyl sulfoxide, vol $/ \mathrm{vol})$ was added to the medium and petri dishes were placed in the dark. Stomata were observed using a fluorescence microscope (DMLB), equipped with a L5 filter ( $\lambda \operatorname{exc} 480$ to $540 \mathrm{~nm}$, $\lambda$ em 527 to $630 \mathrm{~nm}$ ). Imaging of stomata was performed using a camera adapted on the microscope. Because the probe is highly photosensitive (Murata et al. 2001), eight pictures of stomata were rapidly recorded for each epidermal peel. The mean of the intensities of gray levels were measured using the Visiolog software (Noesis, Johannesburg, South Africa).

\section{Transpiration of excised leaves.}

The second leaves from the top of plants were detached and the lower part of the petiole was dipped in a tube containing 15 $\mathrm{ml}$ of ABA (50 or $100 \mu \mathrm{M}$ ) or elicitor (Lam13, OGA, or PS3 at $100 \mu \mathrm{g} \mathrm{ml}^{-1}$ ) solutions or methanol at $0.25 \%$ in water as a control. After $3 \mathrm{~h}$ of treatment, transpiration was estimated as already described (Allègre et al. 2007). Briefly, in order to quantify the water loss, the whole leaf was weighed together with the tube at the beginning and end of the experiment. The leaf surface was determined with a planimeter ( $\mathrm{Li} 3100$ area meter, Li-Cor Biosciences, Lincoln, NE, U.S.A.). Five leaves were used per condition. The experiment was repeated three times.

\section{Thermal imaging.}

Leaves used for transpiration measurements were placed on a plane surface. Digital thermal images were recorded using a thermic camera (Therma CAM E2; FLIR Systems AB, Danderyd, Sweden), as previously described (Allègre et al. 2007).

\section{Localization of $\mathrm{H}_{2} \mathrm{O}_{2}$ in elicitor-treated and $P$. viticola-infected leaves.}

Plants were treated by elicitors (PS3, Lam13, and OGA at 5 $\mathrm{mg} \mathrm{ml}^{-1}$ ) or surfactant (kept confidential) at $0.05 \%$ in water as a control and inoculated 2 days later by a suspension of $P$. viticola sporangia $\left(10^{4}\right.$ sporangia $\left.\mathrm{ml}^{-1}\right)$. Leaves were detached at several time points ( $24 \mathrm{~h}$ before inoculation and 24 and $48 \mathrm{hpi}$ ) and placed in DAB-HCl at $1 \mathrm{mg} \mathrm{ml}^{-1}$ as described by ThordalChristensen and associates (1997). $\mathrm{H}_{2} \mathrm{O}_{2}$ was visualized as a reddish-brown coloration.

\section{Statistical analysis.}

Data were analyzed by one-way analysis of variance and means were compared using the least significant difference test.

\section{ACKNOWLEDGMENTS}

We thank Goëmar SA (Saint-Malo, France) for providing oligosaccharadic elicitors; G. Roblin (University of Poitiers, France), who kindly gave us chitosan; and the Conseil Régional de Bourgogne and Moët et Chandon (Epernay, France) for financial support.

\section{LITERATURE CITED}

Adie, B., Pérez-Pérez, J., Pérez-Pérez, M., Godoy, M., Sánchez-Serrano, J., Schmelz, E., and Solano, R. 2007. ABA is an essential signal for plant resistance to pathogens affecting JA biosynthesis and the activation of defenses in Arabidopsis. Plant Cell 19:1665-1681. 
Aït Barka, E., Eullafroy, P., Clément, C., and Vernet, G. 2004. Chitosan improves development, and protects Vitis vinifera L. against Botrytis cinerea. Plant Cell Rep. 22:608-614.

Allègre, M., Daire, X., Héloir, M. C., Trouvelot, S., Mercier, L., Adrian, M., and Pugin, A. 2007. Stomatal deregulation in Plasmopara viticolainfected grapevine leaves. New Phytol. 173:832-840.

Asselbergh, B., De Vleesschauwer, D., and Höfte, M. 2008. Global switches and fine-tuning-ABA modulates plant pathogen defense. Mol. Plant-Microbe Interact. 21:709-719.

Assmann, S.,M. 1993. Signal transduction in guard cells. Annu. Rev. Cell Biol. 9:345-75.

Audenaert, K., De Meyer, G. B., and Hofte, M. M. 2002. Abscisic acid determines basal susceptibility of tomato to Botrytis cinerea and suppresses salicylic acid-dependent signaling mechanisms. Plant Physiol. 128:491-501.

Aziz, A., Poinssot, B., Daire, X., Adrian, M., Bézier, A., Lambert, B., Joubert, J., and Pugin, A. 2003. Laminarin elicits defense responses in grapevine and induces protection against Botrytis cinerea and Plasmopara viticola. Mol. Plant-Microbe Interact. 16:1118-1128.

Bari, R., and Jones, J. 2009. Role of plant hormones in plant defence responses. Plant Mol. Biol. 69:473-488.

Bittelli, M., Flury, M., Campbell, G. S., and Nichols, E. J. 2001. Reduction of transpiration through foliar application of chitosan. Agric. For. Meteorol. 107:167-175

Bradley, D., Kjellbom, P., and Lamb, C. 1992. Elicitor- and woundinduced oxidative cross-linking of a proline-rich plant cell wall protein : A novel, rapid defense response. Cell 70:21-30.

Brisson, L. F., Tenhaken, R., and Lamb, C. 1994. Function of oxidative cross-linking of cell wall structural proteins in plant disease resistance. Plant Cell 6:1703-1712.

Bruce, R. J., and West, C. A. 1989. Elicitation of lignin biosynthesis and isoperoxydase activity by pectic fragments in suspension-cultures of castor bean. Plant Physiol. 91:889-897.

Dai, G. H., Andary, C., Mondolot-Cosson, L., and Boubals, D. 1995. Histochemical studies on the interaction between three species of grapevine, Vitis vinifera, V. rupestris and V. rotundifolia. Physiol. Mol. Plant Pathol. 46:177-188.

Davies, D. R., Bindschedler, L. V., Strickland, T. S., and Bolwell, G. P. 2006. Production of reactive oxygen species in Arabidopsis thaliana cell suspension cultures in response to an elicitor from Fusarium oxysporum: Implications for basal resistance. J. Exp. Bot. 57:1817-1827.

Desikan, R., Cheung, M. K., Bright, J., Henson, D., Hancock, J. T., and Neill, S. J. 2004. ABA, hydrogen peroxide and nitric oxide signaling in stomatal guard cells. J. Exp. Bot. 55:205-212.

Flors, V., Ton, J., Jakab, G., and Mauch-Mani, B. 2005. Abscisic acid and callose: Team players in defense against pathogens? J. Phytopathol. 153:377-383

Garcia-Brugger, A., Lamotte, O., Vandelle, E., Bourque, S., Lecourieux, D., Poinssot, B., Wendehenne, D., and Pugin, A. 2006. Early signaling events induced by elicitors of plant defenses. Mol. Plant-Microbe Interact. 19:711-24.

Gindro, K., Pezet, R., and Viret, O. 2003. Histological study of the responses of two Vitis vinifera cultivars (resistant and susceptible) to Plasmopara viticola infections. Plant Physiol. Biochem. 41:846-853.

Guimaraes, R. L., and Stotz, H. U. 2004. Oxalate production by Sclerotinia sclerotiorum deregulates guard cells during infection. Plant Physiol. 136:3703-3711.

Hamiduzzaman, M. M., Jakab, G., Barnavon, L., Neuhaus, J. M., and Mauch-Mani, B. 2005. $\beta$-Aminobutyric acid-induced resistance against downy mildew in grapevine acts through the potentiation of callose formation and jasmonic acid signaling. Mol. Plant-Microbe Interact. 18:819-829.

Heath, M. C. 1980. Reactions of nonsuscepts to funga1 pathogens. Annu. Rev. Phytopathol. 18:211-236.

Hetherington, A.M. 2001. Guard cell signaling. Cell 107:711-714.

Jabs, T., Tschope, M., Colling, C., Hahlbrock, K., and Scheel, D. 1997. Elicitor-stimulated ion fluxes and $\mathrm{O}_{2}$ from the oxidative burst are essential components in triggering defense gene activation and phytoalexin synthesis in parsley. Proc. Natl. Acad. Sci. U.S.A. 94:4800-4805.

Jones, J. D., and Dangl, J. L. 2006. The plant immune system. Nature 444:323-329.

Kiefer, B., Riemann, M., Buche, C., Kassemeyer, H. H., and Nick, P. 2002. The host guides morphogenesis and stomatal targeting in the grapevine pathogen Plasmopara viticola. Planta 215:387-393.

Klüsener, B., Young, J. J., Murata, Y., Allen, G. J., Mori, I. C., Hugouvieux, V., and Schroeder, J. I. 2002. Convergence of calcium signaling pathways of pathogenic elicitors and abscisic acid in Arabidopsis guard cells. Plant Physiol. 130:2152-2163

Kortekamp, A. 2003. Leaf surface topography does not mediate tactic response of Plasmopara-zoospores to stomata. J. Appl. Bot. 77:41-46.
Lamb, C., and Dixon, R. A. 1997. The oxidative burst in plant disease resistance. Annu. Rev. Plant Physiol. Plant Mol. Biol. 48:251-275.

Lecourieux, D., Mazars, C., Pauly, N., Ranjeva, R., and Pugin, A. 2002. Analysis and effects of cytosolic free calcium increases in response to elicitors in Nicotiana plumbaginifolia cells. Plant Cell 14:2627-2641.

Lee, S., Choi, H., Suh, S., Doo, I. S., Oh, K. Y., Choi, E. J., Taylor, A. T. S., Low, P. S., and Lee, Y. 1999. Oligogalacturonic acid and chitosan reduce stomatal aperture by inducing the evolution of reactive oxygen species from guard cells of tomato and Commelina communis. Plant Physiol. 121:147-152.

Leung, J., Merlot, S., and Giraudat, J. 1997. The Arabidopsis abscisic acid-insensitive2 $(A B I 2)$ and $A B I 1$ genes encode homologous protein phosphatase $2 \mathrm{C}$ involved in abscisic acid signal transduction. Plant Cell 9:759-771.

Levine, A., Tenhaken, R., Dixon, R., and Lamb, C. 1994. $\mathrm{H}_{2} \mathrm{O}_{2}$ from the oxidative burst orchestrates the plant hypersensitive disease resistance response. Cell 79:583-593

Li, J., and Assmann, S. M. 1996. An abscisic acid-activated and calciumindependent protein kinase from guard cells of fava bean. Plant Cell 8:2359-2368.

Mauch-Mani, B., and Mauch, F. 2005. The role of abscisic acid in plantpathogen interactions. Curr. Opin. Plant Biol. 8:409-414.

McAinsh, M. R., Brownlee, C., and Hetherington, A..M. 1990. Abscisic acid-induced elevation of guard cell cytosolic $\mathrm{Ca}^{2+}$ precedes stomatal closure. Nature 343:186-188.

Melotto, M., Underwood, W., Koczan, J., Nomura, K., and He, S. Y. 2006. Plant stomata function in innate immunity against bacterial invasion. Cell 126:969-980.

Melotto, M., Underwood W., and He, S. Y. 2008. Role of stomata in plant innate immunity and foliar bacterial diseases. Annu. Rev. Phytopathol. 46:101-122.

Ménard, R., Alban, S., de Ruffray, P., Jamois, F., Franz, G., Fritig, B., Yvin, J., and Kauffmann, S. 2004. $\beta$-1,3 Glucan sulfate, but not beta-1,3 glucan, induces the salicylic acid signaling pathway in tobacco and Arabidopsis. Plant Cell 16:3020-3032.

Mishra, G., Zhang, W. H., Deng, F., Zhao, J., and Wang, X. M. 2006. A bifurcating pathway directs abscisic acid effects on stomatal closure and opening in Arabidopsis. Science 312:264-266.

Murata, Y., Pei, Z. M., Mori, I. C., and Schroeder, J. 2001. Abscisic acid activation of plasma membrane $\mathrm{Ca}^{2+}$ channels in guard cells requires cytosolic $\mathrm{NAD}(\mathrm{P}) \mathrm{H}$ and is differentially disrupted upstream and downstream of reactive oxygen species production in abi1-1 and abi2-1 protein phosphatase 2C mutants. Plant Cell 13:2513-2523.

Mustilli, A. C., Merlot, S., Vavasseur, A., Fenzi, F., and Giraudat, J. 2002. Arabidopsis OST1 protein kinase mediates the regulation of stomatal aperture by abscisic acid and acts upstream of reactive oxygen species production. Plant Cell 14:3089-3099.

Neill, S. J., Desikan, R., Clarke, A., and Hancock, J. T. 2002. Nitric oxide is a novel component of abscisic acid signaling in stomatal guard cells. Plant Physiol. 128:13-16.

Pei, Z. M., Murata, Y., Benning, G., Thomine, S., Klusener, B., Allen, G. J., Grill, E., and Schroeder, J. I. 2000. Calcium channels activated by hydrogen peroxide mediate abscisic acid signaling in guard cells. Nature 406:731-734.

Poinssot, B., Vandelle, E., Bentéjac, M., Adrian, M., Levis, C., Brygoo, Y., Garin, J., Sicilia, F., Coutos-Thévenot, P., and Pugin, A. 2003. The endopolygalacturonase 1 from Botrytis cinerea activates grapevine defense reactions unrelated to its enzymatic activity. Mol. Plant-Microbe Interact. 16:553-564

Rezzonico, F., Flury, N., Meins, F. J., and Beffa, R. 1998. Transcriptional down-regulation by abscisic acid of pathogenesis related beta-1,3-glucanase genes in tobacco cell cultures. Plant Physiol. 117:585-592.

Schroeder, J. I., and Hagiwara, S. 1989. Cytosolic calcium regulates ion channels in the plasma membrane of Vicia faba guard cells. Nature 338:427-430

Schroeder, J. I., and Hagiwara, S. 1990. Repetitive increases in cytosolic $\mathrm{Ca}^{2+}$ of guard cells by abscisic acid activation of nonselective $\mathrm{Ca}^{2+}$ permeable channels. Proc. Natl. Acad. Sci. U.S.A. 87:9305-9309.

Schulze-Lefert, P., and Robatzek, S. 2006. Plant pathogens trick guard cells into opening the gates. Cell 126:831-834.

Shen, Y. Y., Wang, X. F., Wu, F. Q., Du, S. Y., Cao, Z., Shang, Y., Wang, X. L., Peng, C. C., Yu, X. C., Zhu, S. Y., Fan, R. C., Xu, Y. H., and Zhang, D. P. 2006. The Mg-chelatase $\mathrm{H}$ subunit is an abscisic acid receptor. Nature 443:823-826.

Suhita, D., Kolla, V. A., Vavasseur, A., and Raghavendra, A. S. 2003. Different signaling pathways involved during the suppression of stomatal opening by methyl jasmonate or abscisic acid. Plant Sci. 164:481-488.

Thordal-Christensen, H., Zhang, Z., Wei, Y., and Collinge, D. B. 1997. Subcellular localization of $\mathrm{H}_{2} \mathrm{O}_{2}$ in plants, $\mathrm{H}_{2} \mathrm{O}_{2}$ accumulation in papil- 
lae and hypersensitive response during the barley-powdery mildew interaction. Plant J. 11:1187-1194.

Ton, J., and Mauch-Mani, B. 2004. Beta-amino-butyric acid-induced resistance against necrotrophic pathogens is based on ABA-dependent priming for callose. Plant J. 38:119-130.

Trotel-Aziz, P., Couderchet, M., Vernet, G., and Aziz, A. 2006. Chitosan elicits defense reactions in grapevine leaves and inhibits development of Botrytis cinerea. Eur. J. Plant Pathol. 114:405-413.

Trouvelot, S., Varnier, A.-L., Allègre, M., Mercier, L., Baillieul, F., Arnould, C., Gianinazzi-Pearson, V., Klarzynski, O., Joubert, J.-M., and Pugin, A. 2008. A $\beta-1,3$ glucan sulfate induces resistance in grapevine against Plasmopara viticola through priming of defense responses, including
HR-like cell death. Mol. Plant-Microbe Interact. 21:232-243.

Vandelle, E., Poinssot, B., Wendehenne, D., Bentejac, M., and Alain, P. 2006. Integrated signaling network involving calcium, nitric oxide, and active oxygen species but not mitogen-activated protein kinases in BcPG1-elicited grapevine defenses. Mol. Plant-Microbe Interact. 19:429-440.

Wang, P., and Song, C. P. 2008. Guard-cell signaling for hydrogen peroxide and abscisic acid. New Phytol. 178:703-18.

Willmer, C., and Fricker, M. 1996. Stomata. Second ed. Chapman, Hall, London.

Zeiger, E. 1983. The biology of stomatal guard cells. Annu. Rev. Plant Physiol. 34:441-475. 